\title{
THE IMPACT OF SOCIO-ECONOMIC ACTIVITIES ON ATMOSPHERIC AIR IN THE SOUTH REGION OF THE REPUBLIC OF MOLDOVA
}

\author{
Petru BACAL * \\ Institute of Ecology and Geography, Chișinău, Academiei str. 3, Moldova \\ e-mail: pbacal16@gmail.com \\ Lunita STERPU \\ Institute of Ecology and Geography, Chişinău, Academiei str. 3, Moldova \\ e-mail: luna_md@mail.ru
}

\begin{abstract}
Citation: Bacal, P., Sterpu, L. (2019). The Impact of Socio-Economic Activities on Atmospheric Air in the South Region of the Republic of Moldova. Analele Universităţii din Oradea, Seria Geografie, 29(2), 96-105. https://doi.org/10.30892/auog.292110-824
\end{abstract}

\begin{abstract}
The purpose of this research consists in the elucidation of spatial and branch aspects of the impact of pollution sources on the atmospheric air in the Southern Region of the Republic of Moldova. The main topics presented in this paper are: 1) the dynamics of emissions from fixed and mobile pollution sources; 2) spatial and branch profile of emissions generated by fixed pollution sources: 3 ) existing problems in evaluation and monitoring of emissions sources; 4) the implementation of objectives on adaptation to climate change and low emission economy. The volume of emissions from fixed sources is conditioned by the size of districts and of their urban centers, by the number and capacities of sources from energetics, agri-food complex and fuel stations, and by level of emissions monitoring of environmental authorities. In the majority districts and economic activities is found a oscillatory dynamics of emissions, on the background of a general growth trend.
\end{abstract}

Key words: impact, emissions, region, dynamics, mobile sources, fixed sources

$$
* \quad * \quad * \quad * \quad * \quad *
$$

\section{INTRODUCTION}

The Southern Region occupies an area of 9.2 thousand $\mathrm{km}^{2}$ or more than $1 / 4$ of the total area of the Republic of Moldova. The population of the region is $\approx 700$ thousand inhabitants or $17 \%$ of the total population of the Republic. Within the Southern Region are delimited two development regions: 1) The South Development Region, which comprises 8 districts with a total area of 7.4 thousand $\mathrm{km}^{2}(22 \%)$ and about 530 thousand inhabitants $\left.(13 \%) ; 2\right)$ The Gagauz Development Region, with the area of 1.8 thousand $\mathrm{km}^{2}(5.5 \%)$ and $\approx 170$ thousand inhabitants (4.0\%). Urban populations account for less than $20 \%$ of the total population. Therefore, compared to the other regions of the Republic (Bacal and Sterpu, $2019 \mathrm{a}, \mathrm{b}$ ), the South Region 
has a much lower level of urbanization and industrialization, which conditions a lesser anthropogenic impact on atmospheric air, water resources, on other natural components and the human body. At the same time, the Southern Region is crossed by international and national roads with intense traffic, and the degree of afforestation of the territory is lower than the rest of the regions. In addition, in the proximity of the South Region there are very high sources of pollution, such as the Dnestrovsk Thermoelectric Plant from left bank of Dniester river and the metallurgical plant form Galati, which significantly affect air quality in the study region.

The territory of the Republic of Moldova is extremely vulnerable to the current climate change, which is manifested by the increasing contribution of the anthropic factor. Therefore, reduction and efficiently control of emission has become a key imperative of international politics, stipulated in national strategic documents (Nielsen, 2013; GD no. 1740, 2016; GD no. 1009, 2014; GD no. 301, 2014), in international conventions and agreements on sustainable development and environmental protection (Brega \& Tărîță, 2019). Therefore, studies in the field of assessment and management of emissions of indigenous sources of atmospheric air pollution have not only a theoretical importance, but also a great applicative significance.

Under Objective 7 of the National Environmental Strategy (2014-2023) (GD no. 301, 2014 ), in the field of atmospheric air protection is planned the achieving of two directions of actions: 1) creating of integrated management system of air quality; 2) reduction of pollutant emissions into the atmosphere by $30 \%$ until 2023 , and of greenhouse gases by $20 \%$ until 2020 , compared to 1990 . The main measures planned under the first action are: 1) creating the register of emissions and of pollutants transfers and its inclusion in the integrated environmental information system; 2) elaboration of the mechanism, methodology and instruments for determination of pollutant emission limit values in accordance with local conditions and industrial capacity; 3) optimization of the control system of air quality; 4) creating a national emissions inventory system and setting of national emission ceilings; 5) the introduction of new ecological standards for vehicle emission and fuel quality.

Also, Objective 2 of the National Strategy on Adaptation to Climate Change provides creation and operation of the National Monitoring and Reporting System of Greenhouse Gas Emissions (GD no. 1009, 2014), the adjustment of the existing national methodology (Methodology for calculating concentrations of toxic substances in the atmospheric air from enterprises, 1987) to the European Emissions Assessment Methodology (Nielsen, 2013).

The Low Emissions Development Strategy of the Republic of Moldova (GD no. 1740, 2016) provides the unconditional, until 2030, of the total national emissions of net greenhouse gases, with not less than 64\%, compared to 1990 level, in support of the global effort to maintain the overall global warming trend. The overall objective will be achieved by reducing greenhouse gas emissions in the energetics, transport, agriculture, households, industry, forestry and waste.

\section{MATERIAL AND METHODS}

In this study are included the absolute majority of enterprises and public institutions, the volume of which is about $90 \%$ of the total emissions of fixed sources, with the exception of emissions from communal waste landfills and of emissions from households.

For achieving of the present study have been applied the following research methods: analysis and synthesis, statistical, mathematical, analogical, normative and sociological. Statistical and mathematical methods were used to process statistical data on the volume and toxicological composition of emissions, depending on their branch profile. The analysis and synthesis method were used to identify problematic situations, elaborating of conclusions and recommendations for optimizing the management of emission sources. The sociological method was applied to the consulting of environmental authorities, to interviewing of selected companies in the Southern Region of the Republic of Moldova. The analysed period includes, mostly, the years 2004-2018. 
The main information sources were: Yearbooks of the State Environmental Inspectorate "Environmental Protection in the Republic of Moldova" (2004-2008); Yearbooks of Environmental Agencies and Inspections (2004-2018); National Bureau of Statistics (NBS) reports on atmospheric air protection (2007-2016); National reports on the inventory of greenhouse gases (2017); national strategies in the field (GD no. 1740, 2016; GD no. 1009, 2014; GD no. 301, 2014); methodological guidelines for the assessment and reporting of emissions (Nielsen, 2013; National reports on the inventory of greenhouse gases, 2017; Methodology for calculating concentrations of toxic substances in the atmospheric air from enterprises, 1987). Recent bibliography on national and regional air pollution (Bacal, 2010; Bacal and Sterpu, 2019a, b; Brega \& Tărîță, 2019; Comisia Economică pentru Europa, 2005).

\section{RESULTS AND DISCUSSIONS}

\section{Emissions of mobile sources}

Atmospheric air quality is conditioned by the heavy traffic flow, from which comes about $90 \%$ of the total volume of emissions in the South Region (table 1). The volume of emissions of mobile sources is conditioned by the configuration of the road network and by the intensity of car traffic, as well as by the amount of delivered fuel in the districts and cities of the region. Therefore, the maximum volume of emissions from car transport is attested in the ATU (Autonomous Territorial Unit) of Gagauzia (6.0 thousand tonnes/year), in the districts of Cahul (7.6 thousand t/year), Cimislia (2.7 thousand t/year) and Căuşeni (2.4 thousand t/year) (Environmental Protection in the Republic of Moldova, 2004-2008), and the minimum volume in the smaller districts such as Basarabeasca (449 t/year), Taraclia and Cantemir (1.2 thousand tons/year for each). On the whole, the volume of emissions from mobile sources registered an oscillating evolution, on the background of a general positive dynamics $(+45 \%)$, which is observed in most districts of the region. The maximum increase is recorded in the districts of Taraclia ( 7.6 times) and Cahul (3.3 times), which is conditioned by the construction of the new fuel stations and the multiple increase of the volume of delivered fuel in these districts. In addition, the multiple increase of emissions from mobile sources in the Cahul district is largely due to the small border traffic achieved through the two access ways to Romania (Cahul/Oancea and Giurgiulești/Galați).

The predominance of old cars and the low quality of the used fuel contribute to the air quality reduction in the study region. In urban centers there are significant overruns of admissible concentrations in the perimeter of the overcrowded traffic arteries in the central part of the respective localities (Bacal, 2010, p. 56).

Table 1. The dynamics of volume of emissions generated by mobile sources in the South Region. in tonnes Data source: Environmental Protection in the Republic of Moldova, 2004-2008

\begin{tabular}{|c|c|c|c|c|c|c|c|c|c|c|c|c|c|c|c|c|}
\hline \multirow{2}{*}{ No. } & \multirow{2}{*}{ Districts } & \multicolumn{12}{|c|}{ Years } & \multirow{2}{*}{$\begin{array}{l}\text { ave- } \\
\text { rage }\end{array}$} & \multirow{2}{*}{$\begin{array}{l}\text { Grow } \\
\text { th, } \%\end{array}$} & \multirow{2}{*}{$\begin{array}{c}\text { Share } \\
\%\end{array}$} \\
\hline & & 2007 & 2008 & 2009 & 2010 & 2011 & 2012 & 2013 & 2014 & 2015 & 2016 & 2017 & 2018 & & & \\
\hline 1 & Căuşeni & 2650 & 1600 & 2061 & 2416 & 2197 & 2591 & 2591 & 2697 & 2110 & 2848 & 2221 & 3220 & 2362 & 121 & 82 \\
\hline 2 & Ştefan-Vodă & 1851 & 1791 & 1549 & 2127 & 1117 & 2100 & 2102 & 4485 & 2871 & 2871 & 2211 & 2144 & 2279 & 116 & 85 \\
\hline 3 & Cimişlia & 2622 & 2400 & 2849 & 3487 & 3231 & 3082 & 2539 & 2516 & 2204 & 2302 & 2135 & 2298 & 2670 & 88 & 81 \\
\hline 4 & Basarabeasca & 686 & 353 & 359 & 369 & 369 & 469 & 469 & 469 & 464 & 464 & 469 & 469 & 449 & 68 & 80 \\
\hline 5 & Leova & 4479 & 1325 & 1431 & 1299 & 1258 & 1147 & 1293 & 1187 & 1318 & 1326 & 1523 & 1287 & 1599 & 29 & 83 \\
\hline 6 & Cantemir & 1072 & 857 & 1520 & 1354 & 377 & 1421 & 1721 & 1236 & 1356 & 1356 & 1344 & 1367 & 1238 & 128 & 86 \\
\hline 7 & Cahul & 5910 & 6329 & 17064 & 8392 & 6005 & 5863 & 5491 & 5927 & 7234 & 7234 & 6792 & 19349 & 7476 & 327 & 98 \\
\hline 8 & Taraclia & 218 & 422 & 1218 & 1277 & 1427 & 1451 & 1491 & 1447 & 1298 & 1687 & 1757 & 1663 & 1245 & 763 & 86 \\
\hline 9 & UTA Găgăuzia & 5587 & 5398 & 6602 & 5702 & 5858 & 6172 & 13857 & 4514 & 4990 & 2756 & 4990 & 4508 & 6039 & 81 & 89 \\
\hline & Southern Region & 25075 & 20475 & 34653 & 26424 & 21840 & 24295 & 31553 & 24477 & 23844 & 22843 & 23442 & 36304 & 25356 & 145 & 91 \\
\hline
\end{tabular}




\section{Emissions of stationary sources}

\section{Evidence of stationary source of emissions}

Most fixed emission sources (628 or 37\%) are from the agro-food complex (c.) (table 2), of which predominates the small and medium-sized production units, such as mills, flats and bakeries, public catering enterprises (bars, cafes) predominantly located in rural areas. Also, in the South Region, there are more than 80 wineries, which are a major source of pollution both for air and for water (Environmental Agencies and Inspections, 2004-2018). The absolute majority of medium and large capacity enterprises are located in urban areas, especially in the cities of Cahul, Causeni and Comrat. Poultry factories, slaughterhouses and sausage production enterprises, farms for the cultivation of vegetables and flowers are concentrated in the proximity to the district centers or inside of them. Oils, dairy and cereal production plants are less widespread than northern and central districts (Bacal and Sterpu, 2019 a, b). The maximum number of agro-food enterprises is also registered in ATU Gagauzia (92), in the districts of Leova (165) and Causeni (93).

Table 2. Branch structure and spatial distribution of fixed emission sources in the Southern Region Data sources: Annual Reports (2004-2018) of Environmental Agencies and Inspections

\begin{tabular}{|c|l|c|c|c|c|c|c|c|c|c|c|c|c|c|}
\hline No. & \multicolumn{1}{|c|}{ Districts } & $\begin{array}{l}\text { agri- } \\
\text { food c. }\end{array}$ & $\begin{array}{l}\text { wine- } \\
\text { ries }\end{array}$ & $\begin{array}{l}\text { ener- } \\
\text { getics }\end{array}$ & $\begin{array}{l}\text { fuel } \\
\text { trade }\end{array}$ & $\begin{array}{l}\text { tran- } \\
\text { sports }\end{array}$ & $\begin{array}{l}\text { ser- } \\
\text { vice }\end{array}$ & $\begin{array}{c}\text { MI } \\
\text { BM }\end{array}$ & $\begin{array}{c}\text { wood- } \\
\text { working }\end{array}$ & $\begin{array}{l}\text { light } \\
\text { ind. }\end{array}$ & $\begin{array}{l}\text { comm } \\
\text { unal s. }\end{array}$ & $\begin{array}{c}\text { M } \\
\text { MW }\end{array}$ & $\begin{array}{l}\text { chemi- } \\
\text { cal ind. }\end{array}$ & total \\
\hline 1 & Căuşeni & 93 & 6 & 64 & 25 & 18 & 13 & 10 & 1 & & 2 & & & $\mathbf{2 2 6}$ \\
\hline 2 & Ştefan Vodă & 37 & 6 & 49 & 19 & 3 & & 2 & & & 1 & & & $\mathbf{1 1 1}$ \\
\hline 3 & Cimişlia & 23 & 4 & 47 & 28 & 13 & 6 & 11 & & 1 & & & & $\mathbf{1 2 9}$ \\
\hline 4 & Bas arabeasca & 45 & 5 & 22 & 5 & 14 & 8 & 5 & 4 & 4 & 3 & 1 & 1 & $\mathbf{1 1 2}$ \\
\hline 5 & Cantemir & 56 & 10 & 46 & 9 & 6 & 9 & 3 & & & & 1 & & $\mathbf{1 3 0}$ \\
\hline 6 & Leova & 165 & 10 & 93 & 22 & 13 & 58 & 16 & 5 & 1 & 2 & 2 & 3 & $\mathbf{3 8 0}$ \\
\hline 7 & Cahul & 60 & 13 & 25 & 17 & 11 & 12 & 27 & 6 & 4 & 2 & & 2 & $\mathbf{1 6 6}$ \\
\hline 8 & Taraclia & 57 & 11 & 67 & 15 & 31 & 7 & & 3 & 1 & 3 & 1 & 1 & $\mathbf{1 8 6}$ \\
\hline 9 & ATU Gagauzia & 92 & 19 & 40 & 70 & 22 & 12 & 12 & 4 & 11 & 1 & 7 & & $\mathbf{2 7 1}$ \\
\hline & Southern Region & $\mathbf{6 2 8}$ & $\mathbf{8 4}$ & $\mathbf{4 5 3}$ & $\mathbf{2 1 0}$ & $\mathbf{1 3 1}$ & $\mathbf{1 2 5}$ & $\mathbf{8 6}$ & $\mathbf{2 3}$ & $\mathbf{2 2}$ & $\mathbf{1 4}$ & $\mathbf{1 2}$ & $\mathbf{7}$ & $\mathbf{1 7 1 1}$ \\
\hline
\end{tabular}

On the second position, with 453 units or $26 \%$, is situated the energetics, most of which are thermal plants (boiler rooms) of the mayoralties, educational and medical institutions. The number of sources in the thermo-energetics complex is not only conditioned by the number and size of urban and rural localities, by their thermal energy consumption, by the number of existing public institutions, but and by the level of evidence of the respective sources of emissions. Thus, the maximum number of the emissions sources from energetics is recorded in the districts of Leova (86), Taraclia (67) and Causeni (64). In the last decade, there has been a significant increase of the number and of capacity of thermal plants based on biomass and volume of emissions from these sources, which have a lowest toxicity level than emissions from combustion of fossil fuels. The absolute majority of the biomass-based thermal plants operates at the educational institutions (Environmental Protection in the Republic of Moldova, 20042008; Environmental Agencies and Inspections, 2004-2018). In the South Region, there are 80 biomass-based thermal plants that generate over 250 tons of emissions. Most of these plants are located in the districts of Leova (24), Căuşeni (16), Ştefan Vodă (15) and Taraclia (14), and the maximum volume of emissions from these plants is also recorded in districts of Ştefan Vodă (83 t), Căuşeni (62 t), Taraclia (30 t), Cimişlia (26 t) and Leova (25 t).

Fifth place is the fuel trading companies, with 210 units or $12 \%$, which is far less than the central and northern districts (Bacal and Sterpu, 2019 a, b). The most fuel delivery and storage stations are attested in the ATU Gagauzia (70) and in the districts of Cimislia (28) and Căuşeni (25), which are intersected by roads with more intense traffic. On the fourth place is situated the transport enterprises, with 131 units (7.7\%). In this category were attributed, not only automobile parks and companies of Moldovan Railways, but also car parks, technical service stations of the means of transport. The following position is occupied by service enterprises with 
125 units (table 2) or 7.3\%, most of which are commercial and service centers with a significant presence in the territory (Environmental Agencies and Inspections, 2004-2018). Most service enterprises are located in Leova district (58), where most of the smaller and medium-sized pollution sources have been taken into account.

In the mining and industry of building materials (MIBM) were identified only 86 units $(5.0 \%)$, which is much smaller than the central or northern districts (Bacal and Sterpu, 2019 a, b), in which there are much richer raw materials compared to the South Region. The maximum number of enterprises in this branch is recorded in the Cahul district (25) and is due to the larger dimensions of the Cahul city. At the same time, small enterprises are involved in the production of pressed bricks and paving slabs. The number of enterprises in the other branches does not exceed $1.5 \%$ and is located almost exclusively in the district's centers of the region.

\section{Space and branch analysis of fixed sources of air pollution}

The volume of emissions, which is indicated in the annual reports of statistical and ecological authorities is conditioned by both the level of urbanization and industrialization of the region and the by the evidence and monitoring of atmospheric air pollution sources (Comisia Economică pentru Europa, 2005; Environmental Agencies and Inspections, 2004-2018). At the absolute majority of emission sources, the total volume and the main toxic substances are only estimated, based on the calculation methodology, which are applied since the Soviet period (Methodology for calculating concentrations of toxic substances in the atmospheric air from enterprises, 1987), depending on the type and amount of fuel used and, on the emission, and purification technology. In addition, are not subject to assessment the absolute majority of emissions from communal landfills and animal manure, emissions from households and from small and medium-sized enterprises and organizations. The main causes of this situation are: superficial control of pollution sources; the low number of qualified staff and their huge workload; lack of measurement devices.

After a massive decline in the 1990s, the sum of emissions from fixed sources recorded an oscillating dynamic on the back of a slower growth than mobile emissions (Environmental Protection in the Republic of Moldova, 2004-2008; Environmental Agencies and Inspections, 2004-2018; National reports on the inventory of greenhouse gases, 2017; National Bureau of Statistics (NBS) reports on atmospheric air protection (2007-2016). Also, stationary sources generate only $10 \%$ of total emissions of pollution sources in the region.

According to the Yearbooks of the State Ecological Inspectorate (Environmental Protection in the Republic of Moldova, 2004-2008; Environmental Agencies and Inspections, 2004-2018), in the period of 2004-2018 years, the total volume of emissions of fixed sources of pollution was on average 2.9 thousand tons and in $2018-3.5$ thousand tons (table 3 ). Thus, the amount of emissions generated by stationary sources of pollution in the southern region of the Republic is much lower than the amount of emissions in the northern and central regions, which are larger, but also a higher level of urbanization and industrialization than the South Region. Overall, there is an oscillating evolution of the volume of emissions, conditioned by both the economic fluctuations and the degree of monitoring of the fixed emission sources by the territorial ecological authorities (Bacal, 2010, p. 56). Thus, during the period of general economic growth (2001-2009), there is a significant positive dynamic of the total volume of emissions. Subsequently, as a result of the economic recession, there is a slow negative dynamic, followed by a significant increase in the years 2017-2018, which is mainly due to the increase of evidence and control level of local pollution sources. The positive dynamics of total emissions is recorded in most districts of the region. A multiple increase in emissions is recorded in the districts of Cantemir (4.4 times), Căuşeni (3.4 times), Cimişlia (2.3 times) and ATU Gagauzia (2.5 times). At the same time, in the Leova and Basarabeasca districts, there is a reduction of about 2.5 times of the total volume of emissions. At the same time, in the Leova and Basarabeasca districts, the total emission volume has been reduced by about 2.5 times. 
The volume of emissions of fixed sources is conditioned by the size of their districts and urban centers, by the number and capacities of emission sources from the energetics, from the agro-food complex and fuel stations, and by the monitoring level of emission sources by the environmental authorities. Therefore, the maximum volume of emissions is found in districts of Causeni (516 t), Leova (447 t), Cahul (415 t) and in the ATU Gagauzia (405 t). The minimum volume of emissions is found in the Cantemir (156 t), Basarabeasca (186 t) and Taraclia (198 t) districts with lower dimensions and lower industrialization.

Table 3. The dynamics of emissions volume generated by fixed sources from South Region, in tons Data sources: Annual Reports (2004-2018) of Environmental Agencies and Inspections; National Bureau of Statistics (NBS). Annual Reports (2004-2018) on atmospheric air protection

\begin{tabular}{|c|c|c|c|c|c|c|c|c|c|c|c|c|c|c|c|c|c|c|}
\hline \multirow{2}{*}{ No. } & \multirow{2}{*}{ Districts } & \multicolumn{15}{|c|}{ Years } & \multirow{2}{*}{ average } & \multirow{2}{*}{$\begin{array}{c}\text { Growth } \\
, \%\end{array}$} \\
\hline & & 2004 & 2005 & 2006 & 2007 & 2008 & 2009 & 2010 & 2011 & 2012 & 2013 & 2014 & 2015 & 2016 & 2017 & 2018 & & \\
\hline 1 & Căuşeni & 203 & 342 & 342 & 589 & 499 & 806 & 716 & 500 & 490 & 477 & 520 & 493 & 507 & 558 & 698 & 516 & 344 \\
\hline 2 & Ștefan-Vodă & 443 & 401 & 455 & 343 & 252 & 199 & 199 & 214 & 228 & 213 & 279 & 342 & 373 & 333 & 368 & 310 & 83 \\
\hline 3 & Cimișlia & 237 & 209 & 240 & 248 & 243 & 400 & 277 & 285 & 238 & 206 & 269 & 251 & 252 & 293 & 554 & 280 & 234 \\
\hline 4 & Basarabeasca & 298 & 264 & 157 & 164 & 345 & 270 & 147 & 141 & 141 & 150 & 185 & 180 & 117 & 117 & 117 & 186 & 39 \\
\hline 5 & Leova & 624 & 690 & 490 & 457 & 432 & 912 & 405 & 395 & 378 & 306 & 338 & 319 & 294 & 400 & 267 & 447 & 43 \\
\hline 6 & Cantemir & 52 & 63 & 62 & 65 & 72 & 236 & 203 & 230 & 203 & 165 & 207 & 187 & 184 & 189 & 227 & 156 & 437 \\
\hline 7 & Cahul & 271 & 307 & 264 & 275 & 474 & 532 & 519 & 513 & 518 & 757 & 426 & 382 & 291 & 288 & 407 & 415 & 150 \\
\hline 8 & Taraclia & 180 & 181 & 205 & 197 & 187 & 160 & 167 & 187 & 161 & 162 & 183 & 210 & 285 & 243 & 264 & 198 & 147 \\
\hline 9 & ATU Găgăuzia & 230 & 227 & 234 & 385 & 319 & 287,2 & 336 & 503 & 407 & 473 & 481 & 595 & 450 & 573 & 575 & 405 & 250 \\
\hline & \begin{tabular}{|l} 
Southern Region \\
\end{tabular} & 2538 & 2684 & 2449 & 2723 & 2823 & 3802 & 2969 & 2968 & 2763 & 2910 & 2888 & 2958 & 2752 & 2992 & 3478 & 2913 & 137 \\
\hline
\end{tabular}

In most branches of the economy there is an oscillating evolution of the total volume of emissions from the stationary sources of the region (table 4). A multiple increase of emissions is registered in the communal sector (13 times), service centers (8.4 times), fuel stations (4.2 times), woodworking enterprises (3.4 times) and in machinery and metalworking (M MW) companies - (2.5 times). The insignificant increase of emissions is observed in thermoenergetics and in the agro-food complex. The multiple increase of the volume of emissions from the communal sector is due exclusively to the municipal enterprise from Cahul city, which also assessed the emissions from landfills. A considerable reduction of emissions is recorded in the mining an industry of building materials $(-22 \%)$, in the chemical industry $(-19 \%)$ and in the light industry $(-14 \%)$. In the wine industry, there is a 2.5 times reduction of emissions, which is caused both by the decline of this industry as a result of the blockage on the part of Russia and by the modernization of more competitive wineries.

Table 4. The dynamics of the emissions volume by main economic activities in the Southern Region, in tons Data source: Environmental Agencies and Inspections, 2004-2018

\begin{tabular}{|c|c|c|c|c|c|c|c|c|c|c|c|c|c|c|c|c|c|}
\hline \multirow{2}{*}{ Economic branch } & \multicolumn{15}{|c|}{ Years } & \multirow{2}{*}{ average } & \multirow{2}{*}{$\begin{array}{c}\text { Growth } \\
, \% \\
\end{array}$} \\
\hline & 2004 & 2005 & 2006 & 2007 & 2008 & 2009 & 2010 & 2011 & 2012 & 2013 & 2014 & 2015 & 2016 & 2017 & 2018 & & \\
\hline Energetics & 1130 & 593,7 & 1094 & 983 & 1003 & 1507 & 1363 & 1128 & 1018 & 924 & 1004 & 1022 & 1012 & 1106 & 1323 & 1081 & 117 \\
\hline Agri-food complex & 746,3 & 347,1 & 614,2 & 526 & 523 & 627 & 561 & 704 & 664 & 523 & 650 & 665 & 720 & 750 & 846 & 631 & 113 \\
\hline Fuel trade & 190 & 197 & 277 & 454 & 335 & 360 & 369 & 492 & 376 & 396 & 415 & 507 & 531 & 659 & 793 & 423 & 418 \\
\hline Communal sector & 9,7 & 0,2 & 10,4 & 7,2 & 284 & 330 & 329 & 334 & 338 & 255 & 242 & 148 & 144 & 139 & 126 & 180 & 1303 \\
\hline Transports & 92,6 & 5,7 & 56,1 & 47 & 49 & 56 & 72 & 91 & 103 & 90 & 94 & 106 & 114 & 125 & 139 & 82,6 & 150 \\
\hline MIBM & 121,6 & 67,9 & 122 & 122 & 71 & 56 & 50 & 56 & 48,68 & 60 & 65 & 68 & 90 & 71 & 94 & 77,6 & 78 \\
\hline \begin{tabular}{|l} 
Service \\
\end{tabular} & 11,5 & 4,5 & 8,0 & 14 & 16 & 18 & 18 & 30 & 34 & 52 & 55 & 61 & 63 & 76 & 96 & 37,1 & 838 \\
\hline Woodworking & 10,5 & 1,9 & 22,5 & 19,2 & 45,7 & 29,5 & 28,3 & 39,7 & 38,2 & 36,9 & 37,9 & 37,8 & 38,2 & 39,4 & 35,6 & 30,7 & 340 \\
\hline Light industry & 12,1 & 3,0 & 8,9 & 8,4 & 10,5 & 11,9 & 9,0 & 8,4 & 8,2 & 9,0 & 7,6 & 6,9 & 7,4 & 8,0 & 10 & 8,6 & 86 \\
\hline $\begin{array}{l}\text { Machinery and } \\
\text { metal-working }\end{array}$ & 4,2 & 0,2 & 1,3 & 4,2 & 4,3 & 4,2 & 3,7 & 3,7 & 3,7 & 0,3 & 4,0 & 4,1 & 4,1 & 10,5 & 10,6 & 4,2 & 253 \\
\hline Chemical industry & 2,3 & & 2,2 & 1,8 & 1,9 & 2,5 & 2,3 & 2,5 & 2,3 & 1,5 & 1,1 & 1,9 & 1,9 & 1,9 & 1,9 & 1,9 & 81 \\
\hline Total & 2331 & 1221 & 2216 & 2186 & 2343 & 3003 & 2806 & 2889 & 2635 & 2348 & 2575 & 2628 & 2726 & 2987 & 3476 & 2558 & 149 \\
\hline Wineries & 268 & 91 & 201 & 172 & 163 & 121 & 106 & 178 & 183 & 69 & 84 & 85 & 101 & 97 & 103 & 135 & 39 \\
\hline
\end{tabular}


In the branch structure of emissions of fixed sources, the first positions are occupied by energy $(42 \%)$, the agro-food complex $(25 \%)$ and the fuel trading stations $(17 \%)$, which generate $85 \%$ of total volume of emissions (figures $1-2$ ). The following positions are occupied by communal sector (7\%), transport (3\%) and companies for production of building materials (3\%). The share of other branches is $\leq 1 \%$.

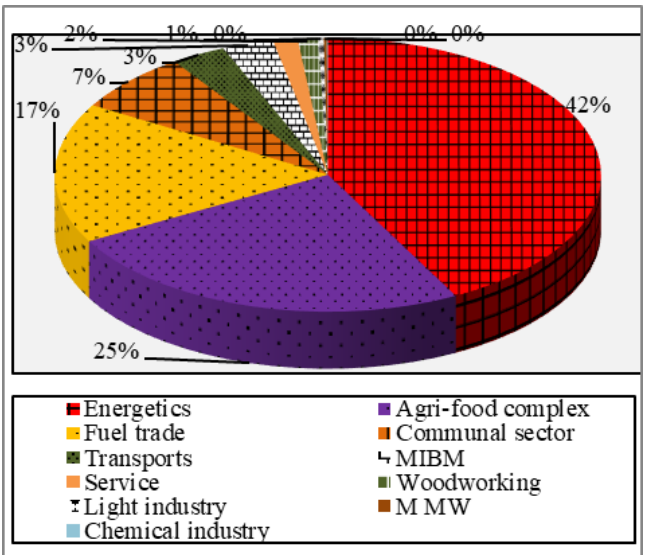

Figure 1. Branch structure of emissions from fixed sources (average of 2004-2018 years)

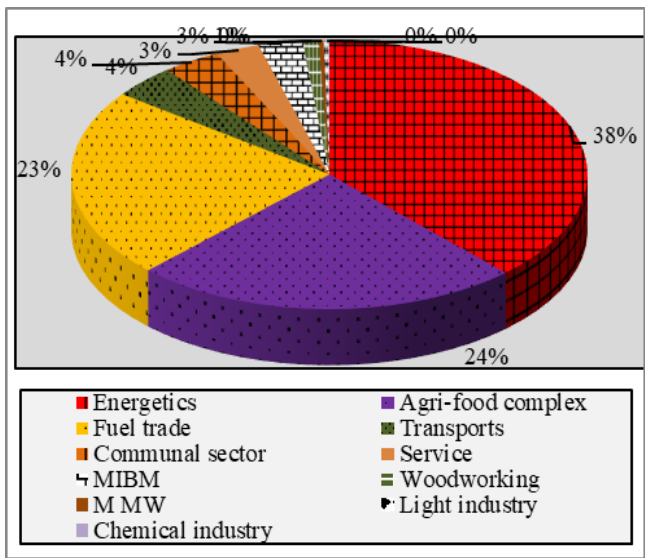

Figure 2. Branch structure of emissions from fixed sources (2018 year)

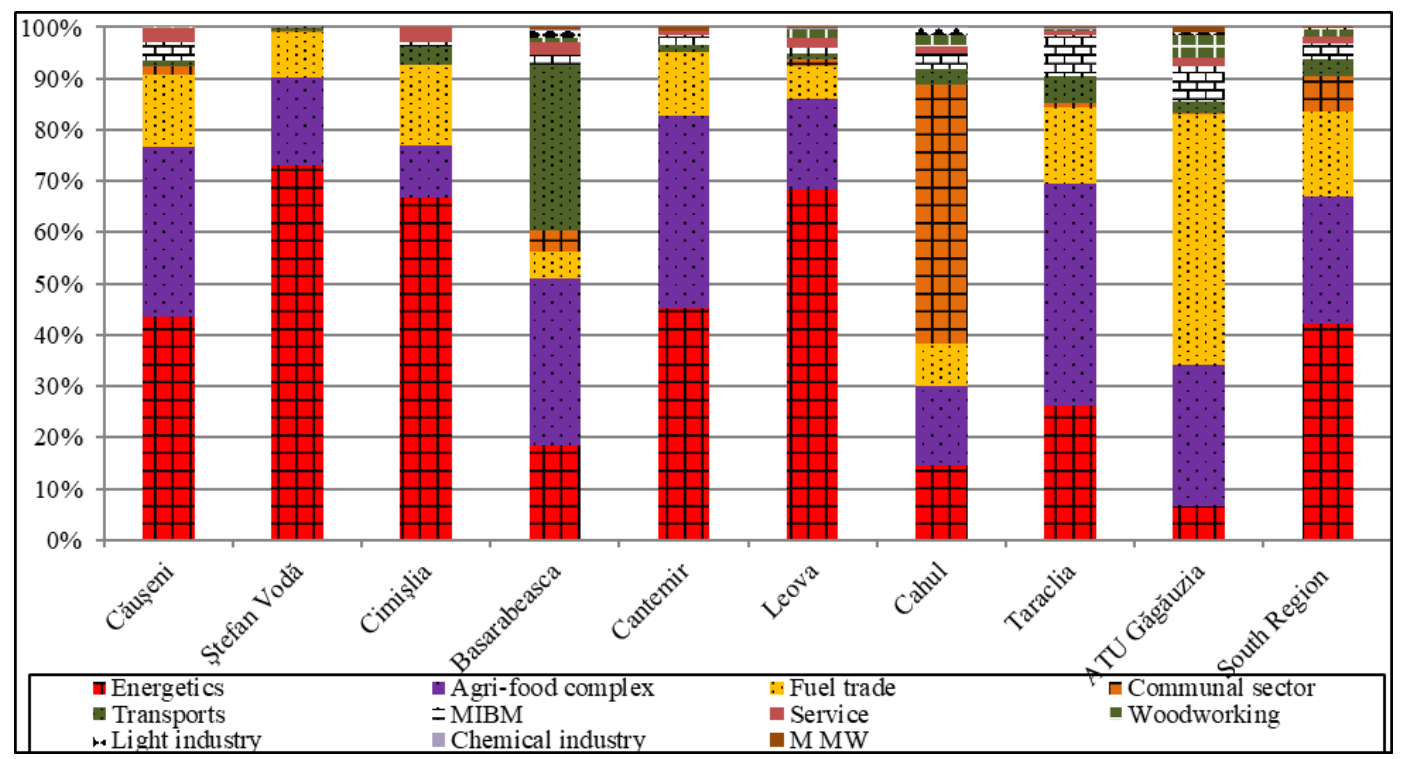

Figure 3. Branch structure of emissions from stationary sources in the districts of South Region (average 2004-2018)

Data source: Environmental Agencies and Inspections, 2004-2018

From energetics are discharged, on average, 42\% (1.1 thousand tons) of emissions from fixed sources (figures 1-2). The volume of emissions and the share of energetics are conditioned by the number and capacities of the thermal plants of administrative, educational and medical institutions, which have provided information on emissions (Environmental Agencies and Inspections, 2004-2018). Thus, a maximum share of over $60 \%$ is attested in the Ştefan-Vodă, 
Cimişlia and Leova districts (figures 3-4). An average share is found in the Causeni and Cantemir districts, and a reduced share $(<20 \%)$ - in the Basarabeasca, Cahul and Taraclia districts. The maximum volume of emissions from energetics is recorded in the districts of Leova $(274 \mathrm{t})$, Causeni $(211 \mathrm{t})$ and the minimum - in the districts of Basarabeasca $(20 \mathrm{t})$, Taraclia $(52 \mathrm{t})$, Cahul $(51 \mathrm{t})$, where the most public institutions did not reported information about emissions (Environmental Agencies and Inspections, 2004-2018).

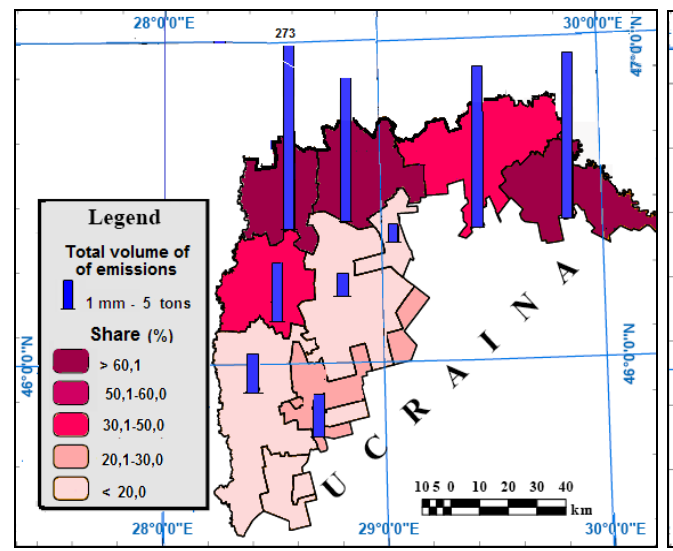

Figure 4. The volume of emissions and the share of energetics in the branch structures of fixed sources in the South Region

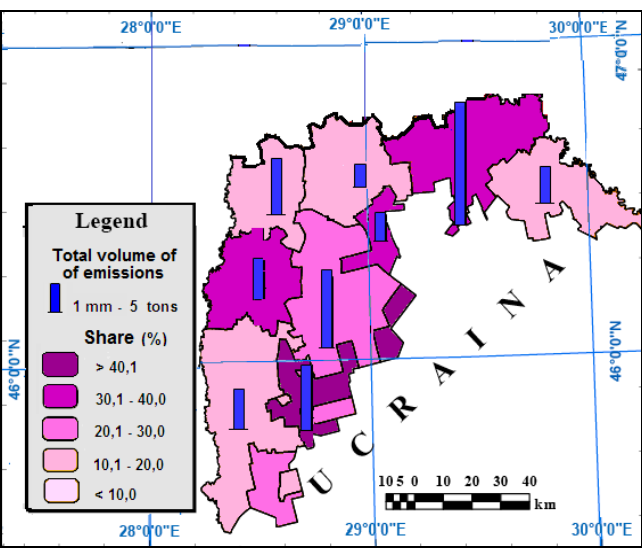

Figure 5. The volume of emissions and the share of agro food complex in the branch structures of fixed sources in the South Region

The agro-food complex is on the second position with, an average, of 630 tons, and in 2018 year -846 tons of emissions or about $1 / 4$ of the total volume of fixed-source emissions from South Region. Agro-food companies have a more balanced share, being distributed relatively uniformly in the all districts of the region. In the Taraclia, Cantemir, Basarabeasca and Căuşeni districts, the agro-food complex's weight exceeds $30 \%$ of the total emissions from fixed sources of air pollution. The minimum $(<15 \%)$ share of agro-food enterprises is observed in the Cahul, Leova and Cimislia districts (figures 3 - 5), which is explained by the absolute predominance of the energetics in the districts and of the communal sector in the Cahul district. In 2018, maximum volumes of emissions from the agro-food complex were discharged in in the ATU Gagauzia (138 t) and in the Causeni (217 t), Taraclia (90 t), Cahul (89 t) districts.

The biggest polluters from the agro-food complex are: wineries (135 t), including from ATU Găgăuzia (35 t)and from districts of Taraclia (26 t), Causeni (17 t), Leova (16 t), Stefan Vodă și Cantemir (14 t each); cereal processing factories from Căuşeni (107 t), Cantemir (55 t), Taraclia (10 t), Iargara and Vulcăneşti; oil production plants from Căuşeni (22 t) and Vulcăneşti; big agricultural companies, especially from Causeni, Basarabeasca, Cantemir and Taraclia districts; poultry farms from Basarabeasca and Cimislia districts; canning factories from ŞtefanVoda (14 t), Căuşeni and Cantemir districts; bakery factories from district centers; mills, flats and bakeries from rural area; public catering enterprises (Environmental Agencies and Inspections, 2004-2018).

The total volume of emissions from fuel stations was, on average, 423 tons or $17 \%$ (figures 1-2), and in $2018 \approx 800$ tons or $23 \%$ of total emissions discharged from fixed sources of air pollution. During the analyzed period there is an increase of more than 4 times of the emissions from the respective branch. The biggest polluters are the gas distribution centers from the district centers; oil stores and fuel trade stations on national roads. Fuel stations have a uniform distribution, being concentrated in the range of urban centers and national routes (Bacal, 2010 p. 62). The maximum share $(\approx 50 \%)$ of the fuel trading stations is attested in ATU 
Gagauzia, and in the districts of the region, the share of the respective branch varies from 5\% to $20 \%$ (figure 3). In 2018, the maximum emissions from the fuel stations are recorded in the ATU Gagauzia (316 t), as well as in Causeni (171 t), Cimislia (93 t) and Stefan Voda (82 t) districts.

The volume of emissions from communal sector was on average 180 tons or $7 \%$ of total volume of emission from stationary sources of air pollution and is due exclusively to the municipal enterprise in Cahul. In the other districts, the share of the communal sector does not exceed $2 \%$ and the volume of registered emissions - 10 tons, which is due to the massive absence of emissions data generated by this branch. At the same time, the harmful impact on the human body is strongly felt next to each treatment plant, and the damages caused to air and water is significant.

The volume of emissions generated by the transport companies is on average 83 tons or $3 \%$, and in 2018 - 139 tons or $4 \%$ of total stationary source emissions from the South Region. The volume of emissions and the share of this branch are conditioned by the size and geographical location of the urban centers, by the number and capacity of the transport companies, and also by the degree of evidence of these emission sources by the environmental authorities. Thus, the maximum share of transports is attested in Basarabeasca district (30\%), where is located an important railway hub. In most districts of the region there is a moderate share of transport companies (1-4\%) (figure 3). The maximum volume of emissions from this branch is registered in the districts of Basarabeasca (35 t), Taraclia (22 t), Causeni (18 t), Cimislia (17 t) and Cahul (16 t).

From mining and industry of building materials (M BM) were discharged, on average, 78 tons and in 2018 - 96 tons of harmful emissions or only $3 \%$ of the total emissions from stationary sources, which is much less than the northern and central regions (Bacal and Sterpu, 2019 a, b). This is explained both by the much lower supply with raw materials for the building materials industry and by the exclusive presence of the small and medium-sized towns. A high share $(\approx 10 \%)$ of M IBM is found in the Taraclia district, while in the rest of the districts, the share of this branch does not exceed $3 \%$. The biggest polluters from the mining and industry of building materials are: building companies, enterprises for producing of pressed bricks and paving slabs, road reconstruction companies from Cahul, Causeni and Taraclia. Emissions from construction sites are estimated superficial, but their impact is harmful and occurs frequently.

Despite the relatively large number and relatively uniform distribution, the volume of emissions from service enterprises was on average only 37.1 tons or $2 \%$, and in $2018-96$ tons or $3 \%$ of total emissions from fixed sources of air pollution (figures 1-3). The amount of emissions and the share of this sector are conditioned by the number and capacity of the service and commercial centers from the region, but also on the level of monitoring of these sources by environmental authorities. The maximum volume of emissions is found in the Leova, Causeni and Cahul districts.

The volume of emissions from woodworking enterprises was, on average, 30.7 tons, and in 2018 - only 35.6 tons or only $1 \%$ of the total emissions from stationary sources. The reduced share of this branch is due both to the much lower afforestation compared to the central districts and to the exclusive presence of small and medium-sized towns in the South Region. Also, because of the low level of urbanization, there is a very low volume of emissions generated by enterprises from the machinery and metalworking industry (M MWI). In addition, most of companies from these branches are located in Cahul city, and in Comrat and Ceadâr Lunga towns from ATU Gagauzia.

\section{CONCLUSIONS}

Road transport generates about $90 \%$ of the total volume of emissions discharged in the South Region. The volume of emissions from mobile sources is conditioned by the configuration of the road network and the intensity of road traffic in the region's districts.

Most of the stationary emission sources are discharged from the agro-food complex $(37 \%)$, the thermo-energetics complex $(26 \%)$, the fuel station $(12 \%)$, from the transport and the 
service centers $(7.3 \%)$. In the last decade, there has been a significant increase of number and capacity of the thermal plants based on biomass and volume of emissions from these sources, which have a lowest toxicity level than emissions from combustion of fossil fuels.

The volume of emissions from fixed sources registered an oscillating evolution on the background of a general trend of slow growth, which is observed in the most economic branches and of districts from the South Region.

In the branch structure of emissions from stationary sources of air pollution in the South Region, the first positions are occupied by the thermo-energetics and agro-food complexes, followed by the fuel stations. The superficial assessments of emission significantly reduce the management efficiency of impact on atmospheric air.

A major impact on atmospheric air is generated by biological wastewater treatment plants, but which episodically presents information on the amount and toxicity of pollutants discharged into the atmospheric air. At the same time, the harmful impact on the air and the human body is strongly felt in the proximity of majority treatment station.

\section{REFERENCES}

Bacal, P. (2010). Gestiunea protecţiei mediului înconjurător în Republica Moldova. Aspecte teoretice și aplicative. Chişinău. ASEM, 240 p.

Bacal, P., \& Sterpu L. (2019a). Impactul activităților economice asupra aerului atmosferic în RD Centru. În: Culegere de articole științifice dedicata m. cor. AȘM Ion Dediu la 85 de ani. Chișinău, pp. 261-269.

Bacal, P., \& Sterpu L. (2019b). Impactul activităților socio-economice asupra aerului în Regiunea de Nord. În: Materialele Conferinței Științifice „Știința în Nordul Republicii Moldova”. Bălți, pp. 268-277.

Brega, V., \& Tărîță, A. (2019). Dinamica poluării aerului atmosferic în contextul convențiilor de mediu. În: Culegere de articole științifice dedicata m. cor. AȘM Ion Dediu la 85 de ani. Chișinău, pp. 124-133.

Nielsen, O. K. (2013). EMEP/EEA air pollutant emission inventory guidebook 2013: Technical guidance to prepare national emission inventories. EEA Technical Report. Luxembourg: EEA-European Environment Agency. doi: $10.2800 / 92722$.

GD no. 1740 of 30.12.2016 for approving The Low Emissions Development Strategy of the Republic of Moldova until 2030. In: Official Monitor of RM no. 85-91 of 24.03.2017

GD no. 1009 of 10.12.2014 for approving The National Strategy on Adaptation to Climate Change until 2020. In: Official Monitor of RM no. 372-384 of 19.12.2014.

GD no. 301 of 24.04.2014 for approving The National Environmental Strategy (2014-2023). In: Official Monitor of RM no. no.104-109 of 06.05. 2014.

Yearbooks of the State Environmental Inspectorate "Environmental Protection in the Republic of Moldova" (2004-2008). Inspectoratul Ecologic de Stat (2004-2018). Anuarele privind calitatea factorilor de mediu şi activitatea Agenţiilor şi Inspecţiilor Ecologice. Chișinău.

Yearbooks of Environmental Agencies and Inspections (2004-2018). Inspectoratul Ecologic de Stat (2004-2018). Protecția mediului în Republica Moldova. Chișinău.

National reports on the inventory of greenhouse gases (2017). Raport Național de Inventariere. Surse de emisii și sechestrare a gazelor cu efect de seră în Republica Moldova.Anii 1990-2015. (2017). Chișinău, 682 p.

National Bureau of Statistics (NBS) reports on atmospheric air protection (2007-2016). Rapoartele BNS „Protecţia aerului atmosferic" pentru anii 2007-2016.

Comisia Economică pentru Europa (2005). Studiu de performanţe în domeniul protecţiei mediului. Republica Moldova Studiul al doilea. Naţiunile Unite New York şi Geneva, 2005, 182 p. https://www.unece.org/fileadmin/DAM/env/epr/epr_studies/moldova\%20II\%20m.pdf

Methodology for calculating concentrations of toxic substances in the atmospheric air from enterprises. (in russian). Leningrad. Ed. Ghidrometeoizdat, 1987. 94 p.

Submitted:

July 20, 2019
Revised:

August 27, 2019
Accepted and published online September 30, 2019 